\title{
Service learning in foundation phase teacher education: Experiential learning opportunities for student teachers
}

\author{
Gadija Petker, University of Johannesburg.* \\ Nadine Petersen, University Johannesburg
}

\begin{abstract}
This paper reports on the implementation of a model that infuses service-learning into a four-year foundation phase teacher education programme. We argue for an integrated curriculum design utilising specifically the teaching (laboratory) school of the faculty, not only for clinical experience or work-integrated learning, but also for service-learning. In this way, the relation of the teacher education programme to the teaching school and its location within Soweto, an area within Johannesburg, optimises the affordances of learning from and through experience for students. The service-learning activities were designed to inform and draw on students' practical and situational learning (learning in and about context) and address the notions of integrated and applied knowledge in the 'Minimum Requirements for Teacher Education Qualifications' (RSA DHET 2011). We argue in this paper that the incremental inclusion of service-learning over a four-year period and the varied nature of the service-learning projects within the programme extend students' learning from practice, provide opportunities for students to see people outside of formal education as 'experts' who have something to contribute to their education, and maximize the potential civic and academic outcomes for students.
\end{abstract}

Keywords: service-learning, foundation phase teacher education, experiential learning, teaching (laboratory) school

*Email address: gadijap@uj.ac.za.

South African Journal of Childhood Education | 2014 4(3): 122-135 | ISSN: 2223-7674 |๑ UJ

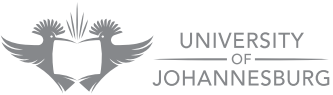




\section{Introduction}

The value of service-learning for student learning has long been the subject of investigations in the field of teacher education internationally (Anderson, Swick \& Yff 2001; Furco \& Root 2010). In South Africa, although a number of teacher education programmes include service-learning, the research on its efficacy is still in its infancy (Bender \& Jordaan 2007; Osman \& Castle 2006). This paper outlines the development and implementation of a model for the infusion of service-learning into a new childhood education teacher education programme at a university in South Africa. Based on the second author's success in incorporating service-learning into a secondary school teacher education curriculum, we have designed a model which incrementally infuses service-learning into the first three years of the students' study programme. In the design of the curriculum we took particular cognisance of the Department of Higher Education and Training (DHET) 2011 policy on the minimum requirements for teacher education (RSA DHET 2011). This policy places an emphasis on students learning in and from practice in order to develop tacit knowledge of the world of teaching. We argue for an integrated curriculum design utilising specifically the teaching (laboratory) school $^{1}$ of the faculty, not just for clinical experience or work-integrated learning, but also to optimise the learning affordances from service-learning.

We outline the various service-learning initiatives and illustrate how the activities and projects associated with each of the specific courses are related to their key purpose and outlines. We also describe how curriculum content and student service is integrated within each of the service-learning projects, with each component playing a specific role in the key focus areas of prospective foundation phase teachers. The service-learning activities and projects have been deliberately designed to build on each other, with students offering service in a teaching school attached to the faculty before moving their activities into the wider Soweto ${ }^{2}$ community. In particular, we were interested in how service-learning could assist students in operationalising a faculty-specific conceptual framework of accountability and reflexivity in their development as teachers. We argue that service-learning brings a particular emphasis to teacher education in that it can serve as integrating factor in the curriculum, while also serving as an experiential learning opportunity about teachers' role as future school community members.

1 Students' work in the teaching school focuses on the study of the developing child. They also conduct observations of children and teach lessons from Grade 1 to Grade 3.

2 Soweto is an urban area of the city of Johannesburg, in Gauteng, South Africa, bordering the city's mining belt in the south. The name is an English syllabic abbreviation for 'South Western Townships'. The area came about in the late nineteenth century as informal accommodation for black South Africans working in the gold mines and as a result of the forced removal of blacks living in the former Transvaal province 


\section{A teaching school in a foundation phase teacher education programme}

The Faculty of Education at the University of Johannesburg (UJ), in partnership with the Gauteng Department of Education, through a memorandum of agreement, founded a public school on the Soweto campus in 2010. The key objectives of this agreement were multiple: serving the education needs of young children close to the UJ Soweto campus; developing a practicum site for the education of teachers of young children; enabling longitudinal child development studies and research on children's performance in the school curriculum; and serving as a resource centre/development hub for schools close to the Soweto campus. The school became known as the UJ's 'teaching school', in accordance with the 'Integrated Strategic Planning Framework for Teacher Education and Development in South Africa' (RSA DBE \& DHET 2011). Activity 4.5 of this document specifically mentions "strengthen[ing] the teaching practice/school experience component of teacher education programmes through the development of teaching schools and professional practice schools" (ibid:18). The framework has as primary outcome the improvement of the quality of teacher education and development. Embedded in this outcome is the assumption that there will be an observable improvement in the quality of teachers and their teaching.

The DHET's 2011 policy on the minimum requirements for teacher education also provides clear requirements for the development of learning programmes and particular guidelines for practical and experiential learning (RSA DHET 2011). There is thus a clear message that universities offering teacher education programmes will need to implement innovative mechanisms to strengthen students' learning from practice. The inclusion of service-learning as a form of experiential and practical learning was therefore carefully planned to optimise the affordances of learning for students, both in terms of the relation of the teacher education programme to the teaching school and the location of the school within Soweto. The service-learning activities were designed to inform and draw on students' learning-in-practice in an authentic classroom and/or school environment and their situational learning (learning in and about context); the policy's notion of integrated and applied knowledge was thus also addressed. In the design process, we argued that servicing the educational needs of children drawn from the Soweto community in a teaching school would help broaden the scale, scope and complexity of students' learning about the children and the conditions of their lives during the course of the service-learning experience. Also, the specific requirements of this community would be addressed through the servicelearning projects, and were therefore instrumental in the curriculation process and in planning for student learning.

\section{Service-learning in teacher education}

The research literature reveals both advantages and disadvantages to incorporating service-learning into teacher education. Several rationales for the advantages are supported by research, mostly in the United States, over the last three decades 
(see Eyler, Giles, Stenson \& Gray 2001). These include its positive effect on students' personal development (Astin \& Sax 1998; Eyler \& Giles 1999; Rockquemore \& Schaffer 2000; Schmidt 2000; Wang 2000); its effect on interpersonal development and the ability to work well with others (Keen \& Keen 1998; McMahon 1998); its influence on the development of leadership and communication skills (Raskoff 1997; Vogelgesang \& Astin 2000; Wade \& Yarborough 1996); its ability to reduce stereotypes and facilitate cultural and racial understanding (Boyle-Baise \& Kilbane 2000); and its strengthening of students' ability to apply what they have learned in the 'real world' (Gelmon, Holland \& Shinnamon 1998; Nigro \& Wortham 1998). Despite the advantages, Erickson and Anderson (1997) also highlight three commonly advanced reasons why teacher educators do not want to incorporate service-learning into their pre-service programs. For many teacher educators who include service-learning in their programmes, the experiential nature of the pedagogy is self-evident and they find it unnecessary to teach its philosophy and foundations explicitly. Others fear that novice teachers have more essential challenges and that service-learning will only take up space in a teacher education programme.

In our view, our precise curriculum planning and design of service-learning opportunities in a whole programme negates the disadvantages mentioned by Erikson and Anderson (1997). We have also drawn optimally on the various rationales for informing our service orientation and approach to service-learning (Morton 1996) in the teacher education curriculum. This approach is in keeping with our underlying philosophical perspective of an "inductive, process-based" pedagogy (ibid:279) in which student experience and voice are central. It also reflects our epistemological position, which recognises the centrality of students' learning as a result of their experiences and views this as a valuable form of knowledge. Such an approach acknowledges and validates students as active contributors to their own learning, and thus to the process of knowledge production, while rendering a service in a school community. In the UJ example, this is exemplified in the integration of service-learning into the teacher education programme over a three-year period, the overall theoretical framework of the course/s that integrate service-learning, and the service-learning projects students execute, all of which are expounded upon in various sections of this paper.

We found the work of Wade (2001) useful in the design process. Wade highlights in her research on SL and student teacher empowerment how stage theory informs the commonly accepted four stages of student teacher development. She argues that student teachers start with a concern with self, motivated chiefly by fear and uncertainty; then a concern with teaching, motivated by the need to find ways of socialisation into the practice; then a focus on pupils' learning and behaviour (which speaks to developing autonomy and affirmation). We used this to inform the design of the $S L$ activities in each year.

Lastly, we draw on arguments forwarded by service-learning researchers and practitioners that "incremental integration" (Berle 2006:43) can lead to more successful service-learning experiences for students and staff. The idea of 
a progressively more complex form of service/engagement was forwarded by Zlotkowski (1999:101) in his presentation of a conceptual matrix for explicating the intersection of academic interests and interest in the learners. Within this matrix, academic presence incorporates a continuum from expertise to concern for the common good, and learner domain includes the classroom and the world beyond the classroom. This is also in line with the arguments of Erickson and Anderson (1997), who say that in order for service-learning to be successful, it should meet a number of conditions. These include that it should be integrated throughout a variety of courses in a teacher education programme; that teacher education programmes should work to create service-learning placements in schools that extend over a substantial period of time; that service-learning placements sites do not need to be ideal models of fully developed service-learning projects; and that pre-service teachers should be granted opportunities to 'start small, but jump in' with service-learning projects in their first year. It is precisely principles such as these that underpin the model we present and discuss in this paper.

\section{A curriculum model for the infusion of service-learning into a primary school teacher education programme}

In order to strengthen the practical component of students' learning as part of becoming a teacher, service-learning is integrated throughout the first three years of their programme, with each section playing a very specific role. This integration is informed by studies that argue for coherence and progression in students' learning about concepts and practices in whole programmes (see for instance DarlingHammond 2006; Moule 2005) and those that argue that the duration and intensity of service have a direct impact on student outcomes (Astin \& Sax 1998; Astin, Sax \& Avalos 1999; Mabry 1998).

Thus, in the first year of the programme the service-learning activities are aligned with the idea of teaching as the practice of caring citizenship (Freeman \& Swick 2001). Students focus on the planning and execution of an 'extracurricular' event at the teaching school. They plan this event according to the theoretical thinking of caring citizenship. During the past four years, this has taken the shape of sport events associated with international competitions, such as the 2011 Rugby World Cup, the 2012 Olympic Games, the 2013 Orange CAF Champions League, and, in 2014, a school sports day. The main aim of these activities has been to broaden the students' understanding of young children's physical development and create opportunities for them to work in teams and experience how this can be optimised through various sporting activities (Table 1).

In the second year, students work on two service-learning projects. The first is an anti-bullying campaign, in which they design a series of interactive plays and games towards this end based on their academic knowledge of how children interact socially with their peers. These games and plays teach learners how to be 'buddies' and interact in friendly and caring ways. It is also aimed at developing students' ability to construct meaningful teaching artefacts for use in a primary school context, which 
they later share with other schools in the Soweto community (Table 1). The second project is linked to the teaching methodology component of a language and literacy course. Here students have to design interactive games based on knowledge they have constructed by using coursework literature. They plan the teaching of reading and storytelling to younger children experiencing difficulties with reading through games and social events. The games provide an opportunity for students to make books and stories come alive. In addition, it serves as a useful tool for students to learn about the teaching of reading, memory retention, and creative problem-solving (Table 1).

The third form of service-learning is lodged in the 'Language for literacy teaching' course, in which the focus is on using children's literature and storytelling. The students' activities extend beyond the teaching school to incorporate the wider Soweto community, including other, often disadvantaged schools in this environment. This reading and literacy festival resonates with the strong indigenous roots of storytelling in African culture and seeks to incorporate this strength into formal reading techniques suitable for young children. Here the focus is specifically on how students can serve the wider Soweto schooling community and develop as agents of change (Zeichner 2009; Chapman \& West-Burnham 2010) through their activities in the two-day storytelling festival which they host and in which they participate (Table 1).

Table 1: Service-learning in curriculum modules over four years

First year

\begin{tabular}{|l|l|l|}
\hline \multicolumn{3}{|c|}{ Teaching Studies 1A } \\
\hline Purpose of the module & Outline of module content & Service-learning in the module \\
\hline $\begin{array}{l}\text { To provide an overview } \\
\text { of the teaching } \\
\text { profession as practice } \\
\text { of citizenship. }\end{array}$ & $\begin{array}{l}\text { Overarching theme: The } \\
\text { teaching profession as } \\
\text { practice of citizenship }\end{array}$ & $\begin{array}{l}\text { The module is structured to } \\
\text { include a service-learning project } \\
\text { that aligns with a theme on 'the } \\
\text { school as community engagement } \\
\text { site'. Based on the needs of the } \\
\text { To prepare students } \\
\text { to become caring, } \\
\begin{array}{l}\text { accountable, } \\
\text { and critically } \\
\text { reflective teachers. }\end{array}\end{array}$ \\
\hline
\end{tabular}

First year

\begin{tabular}{|c|c|c|}
\hline \multicolumn{3}{|c|}{ Education Studies $1 \mathrm{~A}$} \\
\hline Purpose of the module & Outline of module content & Service-learning in the module \\
\hline $\begin{array}{l}\text { To provide students } \\
\text { with an understanding } \\
\text { of children's social and } \\
\text { emotional development. } \\
\text { To equip students to } \\
\text { address social and } \\
\text { emotional issues in and } \\
\text { around the classroom. }\end{array}$ & $\begin{array}{l}\text { - The emotional } \\
\text { development of children } \\
\text { - Social development in } \\
\text { and around the classroom } \\
\text { - Social and emotional } \\
\text { difficulties that children } \\
\text { experience in and around } \\
\text { the classroom }\end{array}$ & $\begin{array}{l}\text { Students designed a series of } \\
\text { interactive plays and games, } \\
\text { based on their academic } \\
\text { knowledge of how children } \\
\text { interact socially with their peers. } \\
\text { 'Be a Buddy Day' - games have } \\
\text { to teach children how to 'be } \\
\text { buddies' or interact in caring and } \\
\text { friendly ways. }\end{array}$ \\
\hline
\end{tabular}


Second year

\begin{tabular}{|c|c|c|}
\hline \multicolumn{3}{|c|}{ Language and literacy for teaching foundation phase $2 \mathrm{~A}$} \\
\hline Purpose of the module & Outline of module content & Service-learning in the module \\
\hline $\begin{array}{l}\text { To guide students } \\
\text { in developing their } \\
\text { own English language } \\
\text { competence and } \\
\text { the requisite subject } \\
\text { knowledge in English } \\
\text { to enable them to } \\
\text { support English } \\
\text { language learning } \\
\text { in the foundation } \\
\text { phase classroom. }\end{array}$ & $\begin{array}{l}\text { - } \\
\text { English grammar } \\
\text { - Diagnostic testing } \\
\text { - } \quad \text { Discourse and genre } \\
\text { literature } \\
\text { - Language through games } \\
\text { and play }\end{array}$ & $\begin{array}{l}\text { Students were tasked with } \\
\text { identifying a learner at Funda } \\
\text { UJabule who was experiencing } \\
\text { difficulties in reading. They then } \\
\text { had to design an interactive game } \\
\text { to assist the learner to improve } \\
\text { his or her reading or literacy skills. } \\
\text { Students then organised a series } \\
\text { of games to play on one Friday of } \\
\text { every month at the school. }\end{array}$ \\
\hline
\end{tabular}

Third year

\begin{tabular}{|l|l|l|l|}
\hline \multicolumn{4}{|c|}{ Language for literacy teaching (English teaching) } \\
\hline Purpose of the module & Outline of module content & Service-learning in the module \\
\hline $\begin{array}{l}\text { To equip students with } \\
\text { the skills and methods } \\
\text { needed to use children's } \\
\text { literature and the English } \\
\text { language effectively }\end{array}$ & $\begin{array}{l}\text { - Social networks } \\
\text { as a foundation } \\
\text { phase teacher. }\end{array}$ & $\begin{array}{l}\text { language learning } \\
\text { literary theory }\end{array}$ & $\begin{array}{l}\text { The SL component is structured } \\
\text { to include a literacy programme } \\
\text { that focuses on story-reading and } \\
\text { storytelling activities at Funda } \\
\text { UJabule School and greater } \\
\text { Soweto Community. }\end{array}$ \\
& $\begin{array}{l}\text { Children's literature } \\
\text { Visual literacy }\end{array}$ & $\begin{array}{l}\text { Thfusing service-learning } \\
\text { in book clubs for reading } \\
\text { book club and reading and writing } \\
\text { theme of the module, as well as } \\
\text { with the blogs and the Internet } \\
\text { for the language learning theme } \\
\text { of the module. }\end{array}$ \\
\hline
\end{tabular}

The essence of the model that has been developed over these years is the core value that care is the flipside of service. Caring relationships therefore are a basic requirement for all participants. We have observed that such relationships take time to evolve, but that they do strengthen over time between the teacher educators, teaching school staff and university students, as well as the children in the school and their families. Students observe their course lecturers working closely with the teaching school staff, other lecturers in the teacher education programme, and members of the school community. They see in this emergent model how outside experts can contribute to their education as future teachers. It also means that the students, who work in the same setting and within the same groups from their first year onwards, must recognise their peer group, community members, and the learners at the school as contributors to their learning (Johnson \& Johnson 2000). This also creates the optimal conditions for students to learn that they have to take an active stance in their own learning to be foundation phase teachers. 


\section{Discussion}

We argue that integrated curriculum design incorporating the teaching school of the faculty not just for clinical experience or work-integrated learning but also for service-learning, holds a number of advantages for strengthening foundation phase teacher education. The value of working with the university teaching school is vested in the nature of the collaboration between the university staff and the school teachers. Staff from both institutions meet regularly to discuss their respective roles and responsibilities in the teacher education component and school segment of the partnership/relationship. The teaching school staff understand and share the UJ's vision of teacher education and thus function not only as school teachers but also as teacher educators.

We argue that the reciprocity that is generated by this type of relationship can spill over into service-learning activities and energise the school as an integrated community. This would mean, firstly, that the school management and staff understand the teacher education curriculum and how students' service towards meeting the school's specific need/s is integrated into their academic learning. Secondly, the disposition and attitudes of the teaching school staff towards servicelearning are enhanced, as they also receive training on the philosophy and pedagogy of service-learning within teacher education; they thus understand its purpose and function and collaborate actively with the UJ's teacher educators and students in the service-learning activities and associated reflections. The success of service-learning is therefore entirely dependent on the relationships between the community being served and the formal university classroom (Bringle \& Hatcher 1996). The community, while clearly a beneficiary of the service-learning, is also an "invaluable source of information, evaluation, and validation of knowledge" (Walshok 1999:81). Thirdly, the teaching school staff are more positively inclined towards accommodating service events within the school day/term, because they are confident that even as the students' learning needs are being met, the school children's learning needs are also being addressed.

These aspects have strengthened the equality of the relationship between the two key partners, which is an essential element for more balanced service-learning. As a result, the school staff are more inclined to act proactively in identifying specific need/s in the school, suggesting projects that will be to the benefit of the school and its wider community, and to work collaboratively with the UJ staff and students to design projects to address specific needs. An example hereof is the recently launched (in 2014) service-learning food gardening project to make school children more aware of the importance of nutritious and affordable food sources, which originated with a request from the school principal. The key objective of the resultant service-learning project is to educate the school children about how to grow nutritious food in easily maintained vegetable gardens, utilising limited resources. The project also aims to promote healthier eating habits and to illustrate self-sufficiency, while at the same time raising awareness about food security in the school community: through the children, their families in the nearby Soweto community may take up the interest 
sparked at school. Students and learners work together in this initiative, using recycled materials as gardening containers and drawing on the teacher education curriculum and elements of the primary school science curriculum.

In addition, in terms of cooperation, an essential element of optimal servicelearning, the partnership between school, university and district office in this model also has the potential to work towards the improvement of foundation phase teacher education. The objectives encapsulated in the MoA enable the teacher educators to leverage service-learning as an additional experiential learning opportunity for students as part of their practicum in the teacher education programme. The service-learning projects, by their very focus on aspects associated with the foundation phase teacher education curriculum, allow for the integration of general pedagogical knowledge, and in particular, general knowledge of learners and instructional strategies, with practical learning (RSA DHET 2011:11). For example, the focus on children's physical development, reading strategies and support, and civic and democratic values provides a third avenue for student learning, in a way that complements what they learn in the formal university classroom and during their practicum/work-integrated learning.

On another level, using the teaching school for service-learning allows the teacher education curriculum planners to make optimal use of the central organising principle or "pedagogical stance" (Feiman-Nemser 2001:1018) of the teacher education programme, which in this institution is knowledge of how children learn and develop. Both the construction of the curriculum and the student teachers' involvement in the teaching school reflect the centrality of child study. For instance, first-year BEd students study a curriculum geared towards Grade $\mathrm{R}$ learners and observe and provide assistance to Grade $\mathrm{R}$ classes in the teaching school. From the second year, the students focus on Grade 1 learners; this is also the time that student teachers begin to teach selected lessons in the school. In their third year, they observe and teach Grade 2 classes. Finally, in the fourth year, students integrate the various dimensions of their studies in the Grade 3 classes. The design of the programme - having students work with consecutive grade levels as they progress from their first to fourth years of study - was based on the argument that student teachers' involvement with the same children over a four-year period would support their development of pedagogical learner knowledge of the foundation phase child. The service-learning fits naturally within this structure. By the time students begin working on their service-learning projects they already have an in-depth understanding of the school children at each particular grade level; students know the children they observe and closely study what the children struggle with and which strengths to build on. It is in this intimate relationship that they begin to experience a sense of school community.

Increasing the service-learning component of the curriculum with each successive course allows all participants - which includes the teacher educators, the teaching school staff and the students - to gradually gain confidence in the method, making it more likely that they will achieve positive results in courses with a larger servicelearning component. The literature is clear that all partners in service-learning initiatives need time to learn the underpinning framework and strategies of 
service-learning in order to succeed (Jacoby 2009; Mitchell \& Rautenbach 2005). This model, which incrementally builds over three years of a teacher education programme, provides such opportunities. Students are grouped with the same set of ten peers for four years, working together as a team in their practicums, class presentations, micro lessons and service-learning projects, which allows them to learn and grow together, so that by the time they get to their third year, they are young 'experts' in executing the service-learning activities. We have observed how sequencing the service-learning projects "maximizes the potential civic and academic outcomes" (Ender, Martin, Cotter, Martstellar-Kowaleski \& Defiore 2000) for students as it builds upon their prior experiences and course concepts (Parker-Gwin \& Mabry 1998). An advantage of this model is that it also creates openings for teacher educators and teaching school staff that are new to the concept of service-learning to be inducted more fully into the pedagogy by senior students who draw on their experience of previous years. As a result, "a more balanced teacher-student relationship emerges, one in which students and teachers become co-investigators into their common reality" (Freire 1974, cited in Jakubowski 2003:25) and are thus jointly responsible for and simultaneously engaged in learning to become a foundation phase teacher.

The inclusion of service-learning in the foundation phase curriculum also has distinct advantages for teacher educators. The lecturers' collaboration with students in the planning and execution of service-learning activities means that their academic interests "extend beyond the traditional goals of course content, student evaluation and faculty tenure" (Zlotkowski 1999:111). We agree with Zlotkowski's views, as we have observed teacher educators becoming "more deliberate in course design" (ibid) and more intent on the overall coherence of the teacher education programme in terms of the skills, knowledge and attitudes required of foundation phase teacher graduates. Another advantage for teacher educators is that service-learning allows them to demonstrate commitment to community engagement as one of their key academic tasks in higher education.

\section{Conclusion}

This paper has outlined a model for the inclusion of service-learning into a childhood teacher education programme, with the specific argument that it can serve as integrating factor for the teacher education curriculum and contains the seeds of school community building by raising a pre-service awareness in students that the ethic of care in education (Noddings 1988) goes beyond the school curriculum, extending to children's lives and touching their families and their home communities (Henning 1997). The model we propose, which incrementally infuses service-learning into the first three years of the students' studies, makes particular use of the close relationship that exists between the university and the teaching school attached to it for building equality and reciprocity in the service exchange - an issue that university lecturers, community partners and researchers constantly struggle with. Such a relationship also facilitates a more organic approach to needs identification, which in turn enables a curriculum development process that integrates what students learn 
in the university classroom with what they learn in the world of practice in the school. This means that service-learning is not regarded as an add-on or as something that takes the place of a more essential component in a teacher education programme. Most importantly, the infusion of service-learning throughout the entire programme, with each successive component building on the preceding one/s, concentrates student learning on key areas of the curriculum, thereby extending students' learning in and from practice. In this way, the process not only builds students' confidence and knowledge of service-learning as pedagogy, but also increases the sustainability of the service-learning projects and partnerships. As service-learning in teacher education is still relatively new in South Africa, this model can provide an example of how it may be used in combination with other experiential learning opportunities to strengthen foundation phase teacher education and instil the idea of the school as a community, raising its children together, both inside and outside the classroom.

\section{Acknowledgement}

The research discussed in this paper was supported by a grant from the Department of Higher Education and Training/European Union for strengthening foundation phase teacher education (2011-2013).

\section{References}

Anderson, J., Swick, K.J. \& Yff, J. (Eds). 2001. Service-learning in teacher education: The growth of new teachers, their students and communities. Washington, DC: AACTE Publications.

Astin, A.W., Sax, L.J. \& Avalos, J. 1999. Long-term effects of volunteerism during the undergraduate years. The Review of Higher Education, 22(2):187-202.

Astin, AW. \& Sax, LJ. 1998. How undergraduates are affected by service participation. Journal of College Student Development, 39(3):251-263.

Bender, G. \& Jordaan, R. 2007. Student perceptions and attitudes about Community Service-Learning before the integration into the curriculum. South African Journal of Education, 27(4):631-654.

Berle, D. 2006. Incremental Integration. A Successful Service-Learning Strategy. International Journal of Teaching and Learning in Higher Education, 18(1):43-48.

Boyle-Baise, M. \& Kilbane, J. 2000. What really happens? A look inside service-learning for multicultural teacher education. Michigan Journal of Community ServiceLearning, 7(1):54-64.

Bringle, R.G. \& Hatcher, J.A. 1996. Implementing service-learning in higher education. Journal of Higher Education, 67(2):221-239.

Chapman, L. \& West-Burnham, J. 2010. Education for social justice. Achieving wellbeing for all. London: Continuum Publishing.

Darling-Hammond, L. 2006. Powerful teacher education: Lessons from Exemplary Programs. San Francisco, CA: Jossey-Bass. 
Ender, M.G., Martin, L., Cotter, D.A., Martstellar-Kowaleski, B. \& Defiore, J. 2000. Given an opportunity to reach out: Heterogeneous participation in optional servicelearning projects. Teaching in Sociology, 28(3):206-219.

Erickson, J.A. \& Anderson, J.B. (Eds.). 1997. Learning with the community: Concepts and models for service-learning in teacher education. Washington, DC: American Association for Higher Education.

Eyler, J. \& Giles, D.E. 1999. Where's the learning in service-learning? San Francisco, CA: Jossey-Bass.

Eyler, J.S., Giles, D.E., Stenson, C.M. \& Gray, C.J. 2001. At a glance: What we know about the effects of service-learning on college students, faculty, institutions and communities, 1993-2000. Third edition. Nashille, TN: Vanderbilt University.

Feiman-Nemser, S. 2001. From preparation to practice: Designing a continuum to strengthen and sustain teaching. Teachers College Record, 103(6):1013-1055.

Freeman, N.K. \& Swick, K.J. 2001. Early childhood teacher education students strengthen their caring and competence through service-learning. In J.B. Anderson, K.J. Swick \& J. Yff (Eds.), Service-learning in teacher education: Enhancing the growth of new teachers, their students, and communities. Washington, DC: AACTE. 134-140.

Furco, A. \& Billig, S. (Eds.). 2002. Service learning: The essence of the pedagogy. Greenwich, CT: Information Age Publishing.

Furco, A. \& Root, S. 2010. Research demonstrates the value of service learning. Phi Delta Kappan, 91(5):16-20.

Gelmon, S.B., Holland, B.A. \& Shinnamon, A.F. 1998. Health professions schools in service to the nation: Final evaluation report. San Francisco, CA: Community Campus Partnerships for Health.

Henning, E. 1997. The school and its communities: learning beyond the curriculum. South African Journal of Education, 17(3):116-124.

Jacoby, B. 2009. Civic Engagement in Higher Education: Concepts and Practices. San Francisco, CA: Jossey-Bass.

Jakubowski, L.M. 2003. Beyond book learning: Cultivating the pedagogy of experience through field trips. Journal of Experiential Education, 26(1):24-33.

Johnson G.W. \& Johnson, R.T. 2000. An educational psychology success story: Social interdependence theory and cooperative learning. Educational Researcher, 38(5):365-379.

Keen, C. \& Keen, J. 1998. Bonner Student Impact Survey. Princeton, NJ: Bonner Foundation.

Mabry, J.B. 1998. Pedagogical variations in service-learning and student outcomes: How time, contact and reflection matter. Michigan Journal of Community Service Learning, 5(1):32-47.

McMahon, R. 1998. Service-learning: Perceptions of pre-service teachers. Paper presented at the Twenty-seventh Annual Meeting of the Mid-South Educational Research Association, New Orleans, LA. 
Mitchell, C. \& Rautenbach, S. 2005. Questioning service-learning in South Africa: Problematising partnerships in the South African context. A case study from the University of KwaZulu-Natal. South African Journal of Higher Education, 19(1):101112.

Morton, K. 1996. Issues related to integrating service-learning into the curriculum. In B. Jacoby \& Associates (Eds.), Service-learning in higher education: Concepts and practices. San Francisco, CA: Jossey Bass. 276-301.

Moule, P. 2005. E-learning for healthcare students: Developing the communities of practice framework. EdD thesis, Bristol: University of the West of England.

Nigro, G. \& Wortham, S. 1998. Service-learning through action research. In R.G. Bringle \& D.K. Duffy (Eds.), Collaborating with the community: Psychology and servicelearning Washington, DC: American Association for Higher Education. 161-170.

Noddings, N. 1988. An ethic of caring and its implications for instructional arrangements. American Journal of Education, 96(2):215-230.

Osman, R. \& Castle, J. 2006. Theorising service-learning in higher education in South Africa. Perspectives in Education, 24(3):63-70.

Parker-Gwin, R. \& Mabry, J.B. 1998. Service-learning as pedagogy and civic education: Comparing outcomes for three models. Teaching Sociology, 26(4):276-291.

Raskoff, S. 1997. Group dynamics in service-learning: Guiding student relations. Michigan Journal of Community Service-Learning, 4(1):109-115.

Rockquemore, K.A. \& Schaffer, R.H. 2000. Toward a theory of engagement: A cognitive mapping of service-learning. Michigan Journal of Community Service-Learning, 7(1):14-23.

Rowls, M. \& Swick, K.J. 2000. Designing teacher education course syllabi that integrate service-learning. Journal of Instructional Psychology, 27(3):187-195.

RSA DBE \& DHET (Republic of South Africa. Departments of Basic Education and Higher Education and Training). 2011. Integrated Strategic Planning Framework for Teacher Education and Development in South Africa: Full version. Retrieved from http://www.education.gov.za/LinkClick.aspx?fileticket=SE\%2fqk1OumtE\%3d \&tabid=677\&mid=1898 (accessed on 05 August 2013).

RSA DHET (Republic of South Africa. Department of Higher Education and Training). 2011. Minimum Requirements for Teacher Education Qualifications. Government Gazette Vol. 553, No. 34467. Pretoria: Government Printers.

Schmidt, B.C. 2000. The service sojourn: Conceptualizing the college student volunteer experience. Unpublished PhD dissertation. Salt Lake City, UT: University of Utah.

Swick, K. \& Brown, M. 1999. The caring ethic in early childhood teacher education. Instructional Pyschology, 26(2):116-120.

Vogelgesang, L.J. \& Astin, A.N. 2000. Toward a theory of engagement: A cognitive mapping of service-learning experiences. Michigan Journal of Community ServiceLearning, 7(1):14-25. 
Wade, R.C. \& Yarbrough, D.B. 1996. Portfolios: A tool for reflective thinking in teacher education. Teaching and Teacher Education, 12(1):3-79.

Wade, R.C. 2001. Social Action in the Social Studies: From the Ideal to the Real. Theory into Practice, 30(1):23-38.

Walshok, M.L. 1999. Strategies for building the infrastructure that supports the engaged campus. In R.G. Bringle, R. Games \& E.A. Malloy (Eds.), Colleges and universities as citizens. Boston, MA: Allyn \& Bacon. 29-44.

Wang, W. 2000. Service-learning: Is it good for you? Paper presented at the Annual Meeting of the American Educational Research Association Conference Roundtable, New Orleans, LA.

Zeichner, K.M. 2009. Teacher education and the struggle for social justice. New York: Taylor and Francis.

Zlotkowski, E. 1999. Pedagogy and engagement. In R.G. Bringle, R. Games, \& E.A. Malloy (Eds.), Colleges and universities as citizens. Boston, MA: Allyn and Bacon. 96-120. 